Reviu Akuntansi dan Bisnis Indonesia, Vol. 4 No. 1, Hlm: 17-27, Juli 2020

Website: http://journal.umy.ac.id/index.php/rab

\title{
Akuntabilitas Pengelolaan Keuangan Desa: Studi Pada Pemerintah Desa di Kecamatan Cibeureum Kabupaten Kuningan
}

\author{
Siti Hasanah ${ }^{1}$, Enung Nurhayati ${ }^{1}$, \& Dendi Purnama ${ }^{1 *}$
}

'Program Studi Akuntansi Universitas Kuningan

\section{N F O A R T I K E L}

\section{Kata Kunci:}

Kualitas Laporan

Keuangan, Kompetensi

Aparatur Pengelola

Keuangan Desa, Sistem

Pengendalian Internal Dan

Akuntabilitas Pengelolaan

Keuangan Desa

Jenis Artikel:

Penelitian Empiris

\section{Korespondensi:}

dendi.purnama@uniku.ac.id

\section{A B S T RAK}

\section{Latar Belakang:}

Adanya tindakan korupsi yang dilakukan oleh aparatur pemerintah desa mengenai penyelewengan penggunaan dana desa di Kecamatan Cibeureum sehingga asas pengelolaan keuangan desa secara akuntabilitas belum sepenuhnya dilaksanakan dengan benar.

Tujuan:

Penelitian ini bertujuan untuk menghasilkan bukti atau fakta empiris tentang pengaruh kualitas laporan keuangan, kompetensi aparatur pengelola keuangan desa dan sistem pengendalian internal terhadap akuntabilitas pengelolaan keuangan desa.

Metode Penelitian:

Populasi dalam penelitian ini adalah aparatur pemerintah desa sewilayah kecamatan Cibeureum dengan unit analisis Kepala desa, Sekretaris desa, kaur keuangan, bendahara desa, ketua BPD, bendahara BPD, ketua LPM dan bendahara LPM. Teknik pengambilan sampel yang digunakan adalah sampel jenuh, dimana seluruh populasi dijadikan sampel sehingga sampel dalam penelitian ini adalah 64 responden. Metode penelitian yang digunakan adalah metode deskriptif dan metode verifikatif. Teknik pengumpulan data menggunakan kuesioner atau angket.

\section{Hasil Penelitian:}

Berdasarkan hasil penelitian menemukan bahwa secara parsial kualitas laporan keuangan, kompetensi aparatur pengelola keuangan desa dan sistem pengendalian internal berpengaruh positif dan signifikan terhadap akuntabilitas pengelolaan keuangan desa.

\section{Keterbatasan Penelitian:}

Keterbatasan dalam penelitian ini terletak pada subjek penelitian yang hanya lingkup kecamatan sehingga untuk penelitian selanjutnya bisa memperluas lingkup penelitian yang lebih luas.

Keaslian/Novetly Penelitian:

Penelitian ini dilakukan pada pemerintah desa di wilayah kecamatan Cibeureum kabupaten Kuningan yang sebelumnya belum ada yang meneliti mengenai pengaruh kualitas laporan keuangan, kompetensi aparatur pengelola keuangan desa dan sistem pengendalian internal terhadap akuntabilitas pengelolaan keuangan desa. 


\section{PENDAHULUAN}

Lahirnya Undang-Undang Nomor 6 Tahun 2014 tentang Desa yang mengemban paradigma dan konsep baru kebijakan tata kelola desa secara nasional. Undang-undang tentang desa telah memberikan kesempatan yang besar bagi desa untuk mengurus tata pemerintahannya sendiri serta pelaksanaan pembangunan untuk meningkatkan kesejahteraan dan kualitas hidup masyarakat desa. Pemerintah desa diharapkan untuk lebih mandiri dalam mengelola pemerintahan dan berbagai sumber daya alam yang dimiliki, termasuk didalamnya kewenangan dalam pengelolaan keuangan desa.

Pasal 93 ayat (1) UU Nomor 6 Tahun 2014 menyatakan bahwa Pengelolaan Keuangan desa meliputi (1) Perencanaan, (2) Pelaksanaan, (3) Penatausahaan, (4) Pelaporan, dan (5) Pertanggungjawaban. Namun, pada tahap perencanaan tidak sesuai dengan situasi yang terjadi di lapangan, di kabupaten Kuningan sendiri tidak semua desa memiliki perencanaan yang baik. Menurut Dinas Pemberdayaan Masyarakat dan Desa (DPMD) Kabupaten Kuningan menyatakan bahwa ada beberapa desa di kabupaten Kuningan yang menyusun Rencana Anggaran Pendapatan Belanja Desa (RAPB Desa) tidak sesuai dengan petunjuk teknis. Mengakibatkan sering dikembalikannya RAPB Desa oleh pemerintah tingkat kecamatan untuk diperbaiki kembali dikarenakan belum relevan dan belum lengkap. Selain itu regulasi penyusunan RAPB Desa yang datangnya kemudian hari menjadi kendala sehingga pemerintah desa harus menyesuaikan dengan regulasi baru.

Tingginya tuntutan yang diberikan kepada pemerintah desa untuk menyelenggarakan pemerintahan yang baik (good governance) di tuntut untuk memberikan informasi pertanggung jawaban khususnya mengenai penggunaan dana desa secara akuntabel yang berlandaskan pada asas Pengelolaan keuangan desa. Akuntabilitas pada dasarnya merupakan suatu bentuk kewajiban pemberian informasi dan pengungkapan atas aktivitas dan kinerja keuangan pemerintah kepada pihak-pihak yang berwenang melalui media pertanggungjawaban secara periodik (Setiawan dkk., 2017). Karena akuntabilitas merupakan salah satu prinsip pemerintah yang good governance. Akuntabilitas dalam pemerintah desa sangat penting karena merupakan salah satu bentuk media pertanggungjawaban pemerintah desa sebagai entitas yang mengelola dana desa. Namun, permasalahan pengelolaan keuangan desa yang tidak efektif dan efisien telah menjadi sorotan publik. Kasus penyelewengan dan korupsi dana desa juga telah mencuat dimedia masa. Kajian tentang Pengelolaan Keuangan Desa oleh KPK (2015) memperoleh hasil bahwa terdapat potensi korupsi dalam pengelolaan keuangan desa yang dapat dilihat dari masalah tata laksana yaitu (1) kerangka waktu siklus pengelolaan anggaran desa sulit dipatuhi oleh desa, (2) APB Desa yang disusun tidak sepenuhnya menggambarkan kebutuhan yang diperlukan desa, (3) transparansi rencana penggunaan dan pertanggungjawaban APB Desa masih rendah, dan (4) laporan pertanggungjawaban yang dibuat desa belum sepenuhnya mengikuti standar dan rawan manipulasi.

Menurut Lembaga Administrasi Negara (2009) menyatakan bahwa pengelolaan keuangan desa dikatakan akuntabel dapat dilihat dari empat indikator akuntabilitas yaitu (1) Kejujuran dan Hukum, (2) Manajerial, (3) Program, (4) Kebijakan. Namun, didalam prakteknya pada indikator Kejujuran dan Hukum belum sesuai dengan situasi yang terjadi di lapangan sehingga pengelolaan keuangan desa belum maksimal. Hal ini dibuktikan dengan adanya pemberitaan di media radarcirebon.com tentang kepala desa di salah satu desa di kecamatan Cibeureum kabupaten Kuningan atas dugaan korupsi dana desa tahun anggaran 2015 dan 2016 hingga menyebabkan kerugian negara sebesar Rp. 407.817.450. Hal ini berdasarkan atas hasil pemeriksaan BPKP tentang dugaan tindak pidana korupsi, adapun pelanggaran yang dilakukan tersangka terkait pengelolaan keuangan desa yang diselewengkan. Pernyataan tersebut juga dibenarkan oleh Dinas Pemberdayaan Masyarakat dan Desa kabupaten Kuningan.

Dengan mengetahui faktor yang mempengaruhi Akuntabilitas pengelolaan keuangan desa, maka aparatur desa dapat menentukan langkah untuk mengatasi masalah-masalah yang timbul. Beberapa faktor yang dapat mempengaruhi akuntabilitas pengelolaan keuangan desa diantaranya adalah kualitas laporan keuangan. Kualitas pelaporan keuangan dimaksud dapat meningkatkan kredibilitasnya dan pada gilirannya akan dapat mewujudkan transparansi dan akuntabilitas 
pengelolaan keuangan. Pemenuhan tujuan dan laporan keuangan akan bermanfaat dan dapat memenuhi tujuannya jika memenuhi empat karakteristik kualitatif laporan keuangan yaitu dapat dipahami (understandability), relevan (relevance), andal (reliability), dan dapat dibandingkan (comparability). Penelitian yang telah dilakukan oleh Fikrian, et al. (2017) mengemukakan bahwa kualitas laporan keuangan berpengaruh signifikan terhadap akuntabilitas pengelolaan keuangan daerah. Namun hal ini tidak sesuai dengan penelitian yang dilakukan Arisman (2015:15) menemukan bahwa kualitas laporan keuangan berpengaruh tidak signifikan terhadap akuntabilitas pengelolaan keuangan daerah.

Selain kualitas laporan keuangan, kompetensi aparatur pengelola keuangan desa mempengaruhi akuntabilitas pengelolaan keuangan desa. Suatu organisasi sektor publik dalam mengelola keuangan masyarakat dituntut harus mampu memberikan laporan keuangan yang bisa dipertanggungjawabkan. Kepala desa selaku aparatur desa menjadi penanggung jawab pengelolaan keuangan dan aset desa. PP No. 11 tahun 2019 pasal 103-104 menyatakan tata cara pelaporan yang wajib dilakukan oleh kepala desa. Kepala desa diwajibkan menyampaikan laporan realisasi pelaksanaan APB Desa kepada Bupati/Walikota setiap semester tahun berjalan (laporan semesteran). Kompetensi yang kompeten dapat mendorong aparatur desa dalam memahami tata cara pengelolaan dana desa dengan baik. Apabila aparatur gagal dalam memahami hal tersebut, maka akan berdampak pada kekeliruan laporan keuangan yang dibuatnya dan ketidaksesuaian laporan dengan standar yang ditetapkan pemerintah, sehingga informasi yang diterima oleh masyarakat menjadi tidak tepat serta dapat mempengaruhi keputusan yang akan diambil selanjutnya. Semakin tinggi kompetensi yang dimiliki aparatur pemerintah deTerisa maka akan meningkatnya akuntabilitas pengelolaan keuangan desa. Rosyidi, et al. (2018) mengemukakan bahwa kompetensi pemerintah desa dalam pengalokasian alokasi dana desa berpengaruh signifikan terhadap akuntabilitas penerintah desa dalam pengelolaan alokasi dana desa. Namun hal ini tidak sesuai dengan penelitian yang dilakukan oleh Widyatama, dkk. (2017) bahwa kompetensi aparatur pemerintah desa tidak berpengaruh signifikan terhadap akuntabilitas pengelolaan keuangan alokasi dana desa.

Pengendalian internal merupakan sistem/prosedur yang ada dalam suatu organisasi untuk menjaga proses kegiatan operasi sesuai dengan kebijakan yang telah ditetapkan guna pencapaian tujuan organisasi itu sendiri. Menurut Krismiaji (2010:218) menyebutkan bahwa pengendalian internal adalah rencana organisasi dan metode yang digunakan untuk menjaga atau melindungi aktiva dan menghasilkan informasi yang akurat dan dapat dipercaya. Pengendalian internal yang baik dan menyeluruh merupakan salah satu upaya mencegah terjadinya kecurangan yang merupakan unsur utama perbuatan korupsi (Ramon dkk., 2014:6). Pengendalian internal dilakukan untuk menjaga proses kegiatan operasi sesuai dengan kebijakan yang telah ditetapkan guna pencapaian tujuan organisasi sehingga pada akhirnya dapat meningkatkan akuntabilitas pengelolaan keuangan desa. Menurut Wardana (2016:71) mengemukakan bahwa pengendalian internal berpengaruh positif terhadap akuntabilitas pengelolaan keuangan desa. Hal ini sejalan dengan penelitian yang dilakukan oleh Yesinia, dkk. (2018) mengemukakan bahwa sistem pengendalian internal berpengaruh positif terhadap akuntabilitas pengelolaan keuangan desa. Namun hal ini tidak sesuai dengan penelitian yang dilakukan oleh Putri (2018:81) ditemukan bahwa sistem pengendalian internal tidak berpengaruh terhadap akuntabilitas pengelolaan keuangan daerah. Penelitian tersebut dilakukan pada pemerintah daerah bukan pada pemerintah desa.

\section{TINJAUAN LITERATUR DAN PERUMUSAN HIPOTESIS}

\section{Teori Stewardship (Stewardship Theory)}

Teori yang mendasari penelitian ini adalah stewardship theory (Donaldson \& Davis, 1991), yang menggambarkan situasi dimana para manajemen tidaklah termotivasi oleh tujuan-tujuan individu tetapi lebih ditujukan pada sasaran hasil utama mereka untuk kepentingan organisasi. Teori stewardship dapat diterapkan dapat menjelaskan eksistensi Pemerintah Desa (steward) 
sebagai suatu lembaga yang dapat dipercaya dan bertindak sesuai dengan kepentingan publik dengan melaksanakan tugas dan fungsinya dengan tepat untuk kesejahteraan masyarakat (principal). Pemerintah desa melaksanakan tugasnya dalam membuat pertanggungjawaban keuangan berupa penyajian laporan keuangan yang akuntabel dan transparan sesuai dengan karakteristik laporan keuangan (relevan, andal, dapat dipahami dan dapat dibandingkan) (Wardana, 2016: 26).

\section{Akuntabilitas Pengelolaan Keuangan Desa}

Akuntabilitas diartikan sebagai elemen penting dalam mencapai good governance atau pengelolaan pemerintah yang baik (Huque, 2011). LAN dan BPKP (2000:43) mengemukakan bahwa akuntabilitas adalah "kewajiban untuk memberikan pertanggungjawaban atau menjawab dan menerangkan kinerja dan tindakan seseorang/ badan hukum/ pimpinan suatu organisasi kepada pihak yang memiliki hak atau kewenangan untuk mempertanggungjawabkan.” Menurut Setiawan dkk. (2017)), pada dasarnya akuntabilitas merupakan pemberian informasi dan pengungkapan atas aktifitas dan kinerja keuangan pemerintah kepada pihak-pihak yang berkepentingan.

\section{Pengelolaan Keuangan Desa}

Pasal 93 ayat (1) UU Nomor 6 Tahun 2014 menyatakan bahwa pengelolaan keuangan desa meliputi: perencanaan, pelaksanaan, penatausahaan, pelaporan, dan pertanggungjawaban. Keuangan Desa dikelola berdasarkan praktik-praktik pemerintahan yang baik. Asas-asas Pengelolaan Keuangan Desa sebagaimana tertuang dalam Permendagri Nomor 20 Tahun 2018 yaitu transparan, akuntabel, partisipatif serta dilakukan dengan tertib dan disiplin anggaran.

\section{Kualitas Laporan Keuangan}

Laporan keuangan merupakan suatu pernyataan entitas pelaporan yang terkandung di dalam komponen laporan keuangan. Laporan keuangan sangat diperlukan oleh suatu lembaga/entitas sebagai bentuk pertanggungjawaban pengelolaan keuangan selama sutu periode. Hal ini berlaku untuk pemerintah desa, laporan keuangan diperlukan untuk mempertanggungjawabkan semua aktivitas-aktivitas dalam pengelolaan keuangan desa. Didalam pelaporan keuangan, pemerintah desa dituntut untuk memenuhi unsur kualitatif laporan keuangan seperti unsur relevan, andal, dapat dibandingkan, dan dapat dipahami agar mendapatkan laporan keuangan yang berkualitas. Laporan keuangan yang berkualitas merupakan salah satu bentuk pelaksanaan akuntabilitas pengelolaan keuangan publik. Dengan demikian tidak adanya laporan keuangan berkualitas menunjukan lemahnya akuntabilitas. Lebih lanjut lemahnya akuntabilitas tersebut mengindikasikan lemahnya sistem yang selanjutnya berimbas pada membudayannya korupsi sistematik. Semakin berkualitas laporan keuangan maka akuntabilitas pengelolaan keuangan desa akan semakin baik. Sebaliknya jika laporan keuangan tidak berkualitas, maka akan terjadi penurunan dalam Akuntabilitas Pengelolaan Keuangan Desa.

Penelitian Fikrian et al. (2017) menguji pengaruh kualitas laporan keuangan terhadap akuntabilitas pengelolaan keuangan daerah. menurut hasil penelitian tersebut kualitas laporan keuangan berpengaruh positif terhadap akuntabilitas pengelolaan keuangan daerah.

$\mathbf{H}_{1}$ : kualitas laporan keuangan berpengaruh positif terhadap akuntabilitas pengelolaan keuangan desa.

\section{Kompetensi Aparatur Pengelola Keuangan Desa}

Kompetensi aparatur merupakan aspek pribadi dari seorang pekerja yang memungkinkan seseorang mencapai kinerja yang baik. Aspek -aspek pribadi ini mencakup sifat, motif, sistem nilai, sikap, pengetahuan dan keterampilan dimana kompetensi akan mengarahkan tingkah laku, 
sedangkan tingkah laku akan menghasikan kinerja. Kompetensi aparatur menjadi suatu faktor yang penting mengingat kompetensi merupakan faktor internal dan menjadi suatu yang penting. Rendahnya kompetensi aparatur dapat menjadi faktor penghambat dalam pengelolaan keuangan desa yang akuntabel. Dengan rendahnya kompetensi serta monitoring dan evaluasi yang kurang efektif mengakibatkan adanya ketidaksesuaian dalam pengelolaan dana desa, sehingga belum mencerminkan pengelolaan yang akuntabel.

Penelitian Rosyidi, et al. (2018) menguji pengaruh Kompetensi pemerintahan desa terhadap akuntabilitas pemerintah desa dalam pengelolaan alokasi dana desa pada pegawai pemerintah desa, dengan hasil penelitiannya menunjukkan kompetensi aparatur desa berpengaruh positif terhadap akuntabilitas pemerintah desa dalam pengelolaan alokasi dana desa.

$\mathbf{H}_{2}$ : Kompetensi aparatur pengelola keuangan desa berpengaruh positif terhadap akuntabilitas pengelolaan keuangan desa.

\section{Sistem Pengendalian Internal}

Sistem pengendalian internal merupakan suatu proses yang didesain untuk memberikan keyakinan yang memadai tentang pencapaian tujuan yang didalamnya terdiri dari keandalan laporan keuangan, efisien dan efektivitas operasi serta ketaatan terhadap undang-undang dan peraturan yang berlaku. Didalam pemerintah desa, pengendalian internal dilakukan untuk menjaga proses kegiatan operasi sesuai dengan kebijakan yang telah ditetapkan guna pencapaian tujuan pemerintah sehingga pada akhirnya dapat meningkatkan akuntabilitas pengelolaan keuangan desa. Jika pengendalian internal suatu pemerintah lemah maka kemungkinan terjadinya kesalahan dan kecurangan semakin besar. Sebaliknya, jika pengendalian internalnya kuat, maka kemungkinan terjadinya kecurangan dapat diperkecil. Keefektifan pengendalian internal mempunyai pengaruh yang besar dalam upaya pencegahan kecenderungan kecurangan akuntansi, dengan tidak terjadinya kecurangan akuntansi akan semakin terwujudnya akuntabilitas laporan keuangan desa.

Dalam Penelitian Aramide \& Bashir (2015) menyatakan bahwa pengaruh sistem pengendalian intern terhadap akuntabilitas pengelolaan keuangan desa dengan hasil penelitiannya menunjukkan terdapat pengaruh positif terhadap akuntabilitas pengelolaan keuangan desa

$\mathbf{H}_{3}$ : Sistem pengendalian internal berpengaruh positif terhadap akuntabilitas pengelolaan keuangan desa.

\section{METODE PENELITIAN}

Metode penelitian yang digunakan adalah metode eksplanasi dan metode verifikatif. Populasi dalam penelitian ini adalah aparatur pemerintah desa yang ditugaskan dalam mengelola keuangan desa se wilayah kecamatan Cibeureum sebanyak 8 desa dengan unit analisis yaitu kepala desa desa, sekretaris desa, kaur kauangan, staf kau keuangan, ketua BPD, bendahara BPD, Ketua LPM dan bendahara LPM sehingga diperoleh sebanyak 64 responden. Teknik pengambilan sampel yang digunakan adalah sampel jenuh, dimana seluruh populasi dijadikan sampel sehingga sampel dalam penelitian ini adalah 64 responden. 


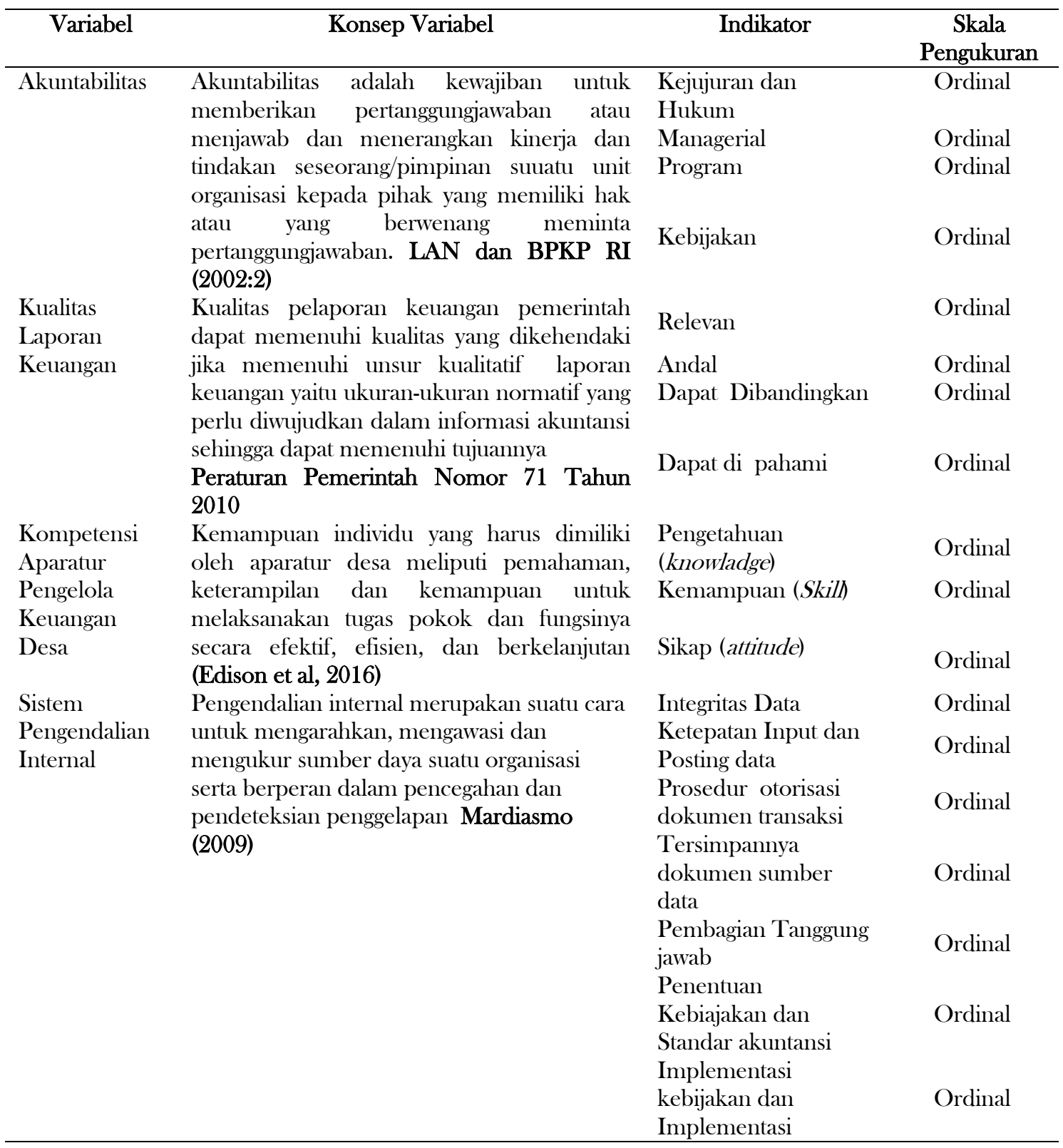

Jenis data yang digunakan dalam penelitian ini adalah data kuantitatif yang bersumber dari data primer yang diperoleh melalui survey dengan menyebar angket/ kuesioner. Teknik analisis data yang digunakan dalam penelitian ini adalah analisis deskriptif, analisis verifikatif dan uji asumsi klasik (uji normalitas, uji multikolinieritas, uji heteroskedastisitas dan uji autokorelasi) sedangkan Analisis statistik dengan menggunakan analisis regresi berganda, koefisien determinasi serta pengujian hipotesis.

\section{HASIL DAN PEMBAHASAN}

Subjek dalam penelitian ini adalah pemerintah desa di wilayah Kecamatan Cibeureum Kabupaten Kuningan. Sedangkan objek penelitian ini adalah Kualitas laporan keuangan, Kompetensi aparatur pemerintah desa, sistem pengendalian internal dan akuntabilitas pengelolaan keuangan desa. Karakteristik responden berdasarkan jenis kelamin dominan berjenis kelamin lakilaki yaitu sebanyak 57 orang $(89,10 \%)$ sedangkan perempuan berjumlah 7 orang (10,90\%). Karekteristik responden berdasarkan usia terdiri dari usia 20-30 tahun sebanyak 12 orang, usia 31- 
40 tahun sebanyak 22 orang, usia 41-50 tahun sebanyak 17 orang dan >50 tahun sebanyak 13 orang. Karakteritisk responden berdasarkan pendidikan terdiri dari lulusan SMA sebanyak 39 orang (60.90\%), D3 sebanyak 3 orang (4,70\%), S1 sebanyak 19 orang (29,70\%), dan S2 sebanyak 2 orang $(3,1)$. Karakteristik responden berdasarkan jabatan terdiri dari Kepala desa, Sekretaris desa, kaur keuangan, staf kaur keuangan, ketua BPD, bendahara BPD, Ketua LPM serta bendahara LPM. Karakteristik responden berdasarkan masa kerja terdiri dari masa kerja 1-5 tahun sebanyak 44 orang $(68,8 \%), 5-10$ tahun sebanyak 13 orang $(20,3 \%),>10$ tahun sebanyak 5 orang $(7,8 \%)$ dan $<1$ tahun sebanyak 2 orang $(3,1 \%)$.

Berdasarkan hasil statistik deskriptif variabel akuntabilitas pengelolaan keuangan desa sebagian besar responden memberikan penilaian atas akuntabilitas pengelolaan keuangan desa pada kategori sangat tinggi yakni sebanyak 282,6 bila dikategorikan jatuh pada interval 268,8-320. Dan dari keseluruhan item variabel Y sebanyak 65,3\% menyatakan selalu, responden sebanyak 21\% menyatakan sering, 7,4\% menyatakan kadang-kadang, 2,9\% menyatakan jarang dan 3,6\% menyatakan tidak pernah.

Berdasarkan hasil statistik deskriptif variabel kualitas laporan keuangan sebagian besar responden memberikan penilaian atas kualitas laporan keuangan pada kategori sangat tinggi yakni sebanyak 290,5 bila dikategorikan jatuh pada interval 268,8-320. Dan keseluruhan item variabel X1 sebanyak 63,6\% menyatakan selalu, responden sebanyak 26,6\% menyatakan sering, 6,1\% menyatakan kadang-kadang , 1,4\% menyatakan jarang dan 2,4\% menyatakan tidak pernah.

Berdasarkan hasil statistik deskriptif variabel aparatur pengelola keuangan desa sebagian besar responden memberikan penilaian atas kompetensi aparatur pengelola keuangan desa pada kategori sangat tinggi yakni sebanyak 280,5 bila dikategorikan jatuh pada interval 268,8-320. Dan dari keseluruhan item variabel X2 sebanyak 54,7\% menyatakan selalu, responden sebanyak 32,2\% menyatakan sering, 11\% menyatakan kadang-kadang, 1,3\% menyatakan jarang dan 1,1\% menyatakan tidak pernah.

Berdasarkan hasil statistik deskriptif variabel sistem pengendalian internal sebagian besar responden memberikan penilaian atas sistem pengendalian internal pada kategori sangat tinggi yakni sebanyak 279,9 bila dikategorikan jatuh pada interval 268,8-320. Dan keseluruhan item variabel X3 sebanyak 53\% menyatakan selalu, responden sebanyak 36,5\% menyatakan sering, 6,8\% menyatakan kadang-kadang, 2,3\% menyatakan jarang dan 1,5\% menyatakan tidak pernah.

\section{Hasil Analisis Data}

Tabel 1

Hasil Uji Validitas

\begin{tabular}{|c|c|c|c|c|c|c|c|}
\hline \multicolumn{2}{|c|}{$\begin{array}{c}\text { Kualitas laporan } \\
\text { keuangan }\end{array}$} & \multicolumn{2}{|c|}{$\begin{array}{l}\text { Kompetensi } \\
\text { Aparatur }\end{array}$} & \multicolumn{2}{|c|}{$\begin{array}{c}\text { Sistem Pengendalian } \\
\text { Internal }\end{array}$} & \multicolumn{2}{|c|}{ Akuntabilitas } \\
\hline $\begin{array}{l}\text { No } \\
\text { item }\end{array}$ & rhitung & $\begin{array}{l}\text { No } \\
\text { item }\end{array}$ & rhitung & No item & rhitung & $\begin{array}{l}\text { No } \\
\text { item }\end{array}$ & rhitung \\
\hline 1 & 0,841 & 1 & 0,636 & 1 & 0,709 & 1 & 0,596 \\
\hline 2 & 0,824 & 2 & 0,615 & 2 & 0,822 & 2 & 0,603 \\
\hline 3 & 0,358 & 3 & 0,788 & 3 & 0,757 & 3 & 0,408 \\
\hline 4 & 0,754 & 4 & 0,651 & 4 & 0,884 & 4 & 0,573 \\
\hline 5 & 0,343 & 5 & 0,804 & 5 & 0,591 & 5 & 0,499 \\
\hline 6 & 0,814 & 6 & 0,552 & 6 & 0,340 & 6 & 0,471 \\
\hline 7 & 0,746 & 7 & 0,609 & 7 & 0,777 & 7 & 0,394 \\
\hline 8 & 0,646 & 8 & 0,586 & 8 & 0,457 & 8 & 0,525 \\
\hline 9 & 0,752 & 9 & 0,722 & & & 9 & 0,489 \\
\hline 10 & 0,909 & 10 & 0,671 & & & 10 & 0,658 \\
\hline 11 & 0,848 & 11 & 0,526 & & & & \\
\hline 12 & 0,798 & & & & & & \\
\hline
\end{tabular}

Sumber: hasil olah data output SPSS 
Berdasarkan tabel di atas dapat diketahui bahwa hasil uji validitas untuk setiap item pernyataan dari masing-masing variabel menunjukkan lebih besar dari $\mathrm{r}$ tabel 0,2075 sehingga dapat disimpulkan bahwa item pernyataan untuk masing-masing variabel dinyatakan valid.

Tabel 2

Hasil Uji Reliabilitas

\begin{tabular}{lccc}
\hline Variabel & Nilai Cronbach's Alpha & N of items & Keterangan \\
\hline Kualiatas laporan keuangan & 0,913 & 12 & Reliabel \\
Kompetensi aparatur & 0,865 & 11 & Reliabel \\
Sistem pengendalian internal & 0,838 & 8 & Reliabel \\
akuntabilitas & 0,631 & 10 & Reliabel \\
\hline
\end{tabular}

Sumber: hasil olah data output SPSS

Berdasarkan tabel di atas dapat diketahui bahwa hasil uji reliabilitas untuk masing-masing variabel menunjukan keandalan tinggi karena lebih besar dari 0,7 sehingga dapat disimpulkan bahwa masing-masing variabel sudah memenuhi kriteria reliabel.

\section{Uji Asumsi Klasik}

Hasil pengujian normalitas dengan uji Kolmogorov-Smirnov untuk masing-masing variabel kualitas laporan keuangan, kompetensi aparatur pengelola keuangan desa, sistem pengendalian internal dan akuntabilitas pengelolaan keuangan desa diperoleh nilai sig. (2-tailed) 0,164, 0,187, 0,552 dan 0,287 lebih besar dibandingkan dengan 0,05. Hal ini bahwa data berdistribusi normal. Hasil pengujian heteroskedastisitas dengan uji Glejser untuk masing-masing variabel kualitas laporan keuangan, kompetensi aparatur pengelola keuangan desa, sistem pengendalian internal diperoleh nilai Sig. 0,590, 0,94, dan 0,234 lebih besar dari 0,05. Hal ini berarti bahwa model regresi dalam penelitian ini tidak terjadi heteroskedastisitas. Hasil pengujian multikolinieritas dengan uji Variance Inflation Factor (VIF) diperoleh nilai VIF untuk masing-masing variabel yang di uji memiliki nilai < 10 . Hal ini bahwa model regresi dalam penelitian ini tidak terjadi multikolinieritas. Hasil pengujian autokorelasi dengan uji Durbin Watson menunjukkan nilai sebesar 2,213. Apabila ingin mengetahui ada tidaknya autoorelasi maka perlu mencari tabel durbin-watson nilai dL dan dU, maka nilai dL diperoleh 1,4990 dan dU diperoleh 1,6946. Sehingga dU s.d 4-Du diperoleh nilai dU nya sebesar 1,6946 s.d 2,3054 (1,6946<2,213<4-1,6946), sehingga dapat disimpulkan bahwa tidak terdapat autokorelasi karena nilai durbin-watson diantara 1,6946 s.d 2,3054.

Tabel 3

Hasil Analisis Statistik Multiple Regression

\begin{tabular}{lccc}
\hline \multicolumn{1}{c}{ Model } & & & \\
\cline { 2 - 4 } & Koefisien & t hitung & Sig. \\
\hline (Constant) & 24,820 & & \\
Kualitas laporan keuangan & 0,470 & 3,766 & 0,000 \\
Kompetensi aparatur & 0,436 & 2,025 & 0,012 \\
Sistem pengendalian internal & 0,411 & 2,896 & 0,004 \\
\hline Koefisien determinasi & & & \\
Adjusted $\boldsymbol{R}$ Square $\left(A d j \cdot \mathbf{R}^{2}\right)$ & 0,516 & & \\
\hline
\end{tabular}

Sumber: Data diolah dari SPSS

Hasil perhitungan statistik diperoleh koefisien determinasi Adjusted R Square sebesar 0,516, artinya sebesar 51,6 persen variasi perubahan variabel akuntabilitas pengelolaan keuangan desa dapat dijelaskan oleh variasi perubahan kualitas laporan keuangan, kompetensi aparatur pengelola keuangan desa dan sistem pengendalian internal sedangkan 48,4 persen dapat dijelaskan oleh variabel lain yang tidak diteliti 
Hasil perhitungan statistik diperoleh nilai thitung untuk kualitas laporan keuangan sebesar 3,766 lebih besar dari nilai t tabel sebesar 1,671 dan nilai sig. t hitung sebesar 0,000 lebih kecil dari nilai alpha 0,05 dengan t hitung mempunyai arah koefisien positif. Maka H0 di tolak dan Ha diterima, artinya bahwa kualitas laporan keuangan berpengaruh positif signifikan terhadap akuntabilitas pengelolaan keuangan desa.

Hasil perhitungan statistik diperoleh nilai thitung untuk kompetensi aparatur pengelola keuangan desa sebesar 2,025 lebih besar dari nilai t tabel sebesar 1,671 dan nilai sig. thitung sebesar 0,012 lebih kecil dari nilai alpha 0,05 dengan t hitung mempunyai arah koefisien positif. Maka H0 di tolak dan Ha diterima, artinya bahwa kompetensi aparatur pengelola keuangan desa berpengaruh positif signifikan terhadap akuntabilitas pengelolaan keuangan desa.

Hasil perhitungan statistik diperoleh nilai thitung untuk sistem pengendalian internal sebesar 2,896 lebih besar dari nilai t tabel sebesar 1,671 dan nilai sig. t hitung sebesar 0,004 lebih kecil dari nilai alpha 0,05 dengan t hitung mempunyai arah koefisien positif. Maka $\mathrm{H} 0$ di tolak dan $\mathrm{Ha}$ diterima, artinya bahwa sistem pengendalian internal berpengaruh positif signifikan terhadap akuntabilitas pengelolaan keuangan desa.

\section{Pembahasan}

\section{Pengaruh Kualitas Laporan Keuangan terhadap Akuntabilitas Pengelolaan Keuangan Desa}

Berdasarkan hasil pengujian hipotesis menunjukkan bahwa kualitas laporan keuangan berpengaruh positif terhadap akuntabilitas pengelolaan keuangan desa, hal ini menunjukkan adanya hubungan yang searah antara kualitas laporan keuangan dengan akuntabilitas pengelolaan keuangan desa. Hal ini mengindikasikan bahwa semakin baik kualitas laporan keuangan maka akuntabilitas pengelolaan keuangan desa akan semakin baik sehingga akan sesuai dengan asas pengelolaan keuangan desa. Sebaliknya jika laporan keuangan tidak berkualitas, maka akan terjadi penurunan dalam akuntabilitas pengelolaan keuangan desa.

Hasil pengujian ini sesuai dengan teori keagenan yang menjelaskan bahwa hubungan keagenan sebagai sebuah kontrak dimana satu atau lebih (principal) menyewa orang lain (agent) untuk melakukan beberapa jasa untuk kepentingan mereka dengan mendelegasikan beberapa wewenang pembuatan keputusan kepada agen. Dalam pelaporan keuangan, pemerintah bertindak sebagai agen yang berkewajiban menyajikan informasi laporan keuangan sesuai dengan karakteristik laporan keuangan (relevan, andal, dapat dipahami dan dapat dibandingkan) bagi para pengguna informasi keuangan pemerintah yang bertindak sebagai prinsipal, digunakan untuk menilai akuntabilitas dan dalam membuat keputusan. Laporan keuangan yang relevan akan membantu pengguna untuk mengevaluasi peristiwa masa lalu, masa kini dan memprediksi masa depan. Laporan keuangan yang andal akan menyediakan informasi keuangan apa adanya, sesuai dengan fakta. Dapat diverifikasi, tidak menyesatkan dan jauh dari kesalahan material membantu pengguna untuk mengambil keputusan. Laporan keuangan yang dapat dibandingkan akan membantu masyarakat mengetahui sejauh mana tingkat kinerja pemerintah. Laporan keuangan yang dapat dipahami yaitu laporan keuangan yang menggunakan bahasa yang dapat dipahami oleh panggunanya dan dapat diinterprestasikan.

Hal ini sesuai dengan hasil penelitian Fikrian et al. (2017) dan Iskandar \& Setiyawati (2015) menyatakan bahwa kualitas laporan keuangan berpengaruh positif terhadap akuntabilitas pengelolaan keuangan desa. Dengan demikian tidak adanya laporan keuangan berkualitas menunjukan lemahnya akuntabilitas. Lebih lanjut lemahnya akuntabilitas tersebut mengindikasikan lemahnya sistem yang selanjutnya berimbas pada membudayannya korupsi sistematik.

\section{Pengaruh Kompetensi Aparatur Pengelola Keuangan Desa terhadap Akuntabilitas Pengelolaan Keuangan Desa}

Berdasarkan hasil pengujian hipotesis menunjukkan bahwa kompetensi aparatur pengelola keuangan desa berpengaruh positif terhadap akuntabilitas pengelolaan keuangan desa. Hal ini 
mengindikasikan bahwa semakin baik kompetensi aparatur pemerintah desa maka semakin baik dalam mengelola keuangan desa sehingga akan terciptanya asas pengelolaan keuangan desa yang akuntabel, transparan dan partisipasi. Dengan sumber daya yang kompeten akan menghasilkan informasi yang berkualitas sehingga harapan masyarakat terhadap aparatur pemerintah desa akan terwujudnya akuntabilitas pengelolaan keuangan desa.

Hasil pengujian ini sesuai dengan stewardship theory dimana dalam teori ini dijelaskan bahwa aparatur pemerintah sebagai pengelola memiliki peran dalam rangka pencapaian tujuan organisasi. Pemerintah desa yang mempunyai aparatur yang kompeten akan memudahkan tata kelola pemerintahana yang baik karena mempunya kemampuan dalam mengelola organisasi sehingga kinerja pemerintah desa akan dipandang baik oleh masyarakat maupun pemerintah daerah sehingga dengan aparatur yang kompeten dapat berdampak pada pengelolaan keuangan desa yang akuntabel dan transparan. Hal ini sejalan dengan penelitian yang dilakukan Rosyidi, et al. (2018) mengemukakan bahwa kompetensi pengelola keuangan desa mempunyai pengaruh positif signifikan terhadap akuntabilitas pemerintah desa dalam pengelolaan keuangan desa

\section{Pengaruh Sistem Pengendalian Internal terhadap Akuntabilitas Pengelolaan Keuangan Desa}

Berdasarkan hasil pengujian hipotesis menunjukkan bahwa sistem pengendalian internal berpengaruh positif terhadap akuntabilitas pengelolaan keuangan desa. Hal ini mengindikasikan bahwa semakin baik sistem pengendalian internal yang diterapkan pada pemerintah desa, maka semakin akuntabel pengelolaan keuangan desa.

Hasil penelitian ini sesuai dengan teori stewardship dimana Pemerintah Desa (steward) sebagai suatu lembaga yang dapat dipercaya dan bertindak sesuai dengan kepentingan publik dengan melaksanakan tugas dan fungsinya dengan tepat untuk kesejahteraan masyarakat (principal). Sistem pengendalian internal berpengaruh dalam terciptanya akuntabilitas pengelolaan keuangan. Dengan adanya sistem pengendalian internal, tindakan penyelewangan yang dilakukan oleh aparatur desa dapat diminimalisir karena adanya prosedur yang harus dijalankan dalam pengelolaan keuangan desa. Selain itu, adanya kontrol dari Badan Permusyawaratan Desa (BPD) maka kegiatan pengelolaan keuangan yang dilakukan pemerintah desa akan terawasi serta dapat meminimalisir adanya tindak kecurangan dalam pengelolaan keuangannya. Sistem pengendalian internal mempunyai dampak dalam menciptakan asas pengelelolaan keuangan desa yang akuntabel. Hal ini sesuai dengan penelitian yang dilakukan (Aramide \& Bashir, 2015) dan Suprihastini, et al. (2017) yang mengemukakan bahwa sistem pengendalian internal berpengaruh positif signifikan terhadap akuntabilitas keuangan.

\section{KESIMPULAN}

Berdasarkan hasil temuan penelitian dan pembahasan yang telah dipaparkan maka dapat disimpulkan bahwa (1) Kualitas laporan keuangan berpengaruh positif terhadap akuntabilitas pengelolaan keuangan desa. Artinya bahwa semakin baik kualitas laporan keuangan maka semakin akuntabel pengelolaan keuangan desa, (2) Kompetensi aparatur pengelola keuangan desa berpengaruh positif signifikan terhadap akuntabilitas pengelolaan keuangan desa. Artinya bahwa semakin kompeten aparatur pengelola keuangan desa akan semakin baik mengelola keuangan desa yang akuntabel, (3) Sistem pengendalian internal berpengaruh positif signfikan terhadap akuntabilitas pengelolaan keuangan desa. Artinya bahwa semakin efektif sistem pengendalian internal akan meningkatkan akuntabilitas pengelolaan keuangan desa.

Keterbatasan dalam penelitian ini terletak pada subjek penelitian yang hanya lingkup kecamatan sehingga untuk penelitian selanjutnya bisa memperluas lingkup penelitian yang lebih luas dan menambah objek penelitian. Adapun saran yang disampaikan dalam penelitian ini adalah sebagai berikut (1) Pemerintah desa hendaknya selalu mendorong aparatur desa untuk selalu memperbarui pengetahuan sesuai dengan bidang pekerjaannya dengan pendidikan maupun 
pelatihan berkelanjutan, Dan (2) Pemerintah desa diharapkan menyampaikan informasi laporan keuangan secara akuntabel dan tranparan agar terwujudnya asas pengelolaan keuangan desa.

Implikasi dari penelitian ini memberikan informasi bahwa kompetensi aparatur pemerintah desa dan sistem pengendalian internal yang baik dapat berdampak pada pelaporan keuangan desa yang akuntabel sehingga dapat mewujudkan tata kelola pemerintah yang baik meskipun terdapat kasus penyalahgunaan wewenang dalam penggunaan dana desa tetapi tidak semua aparatur pemerintah desa di Kecamatan Cibeureum melakukan penyalahgunaan wewenang.

\section{DAFTAR PUSTAKA}

Aramide, S. F., \& Bashir, M. M. (2015). The Effectiveness of Internal Control System and Financial Accountability At Local Government Level in Nigeria. International Journal of Research in Business Management, 3(8), 2321-2886.

Dinas Pemberdayaan Masyarakat Pedesaan Kabupaten Kuningan

Donaldson, L., \& Davis, J. H. (1991). Stewardship Theory or Agency Theory: Australian Journal of Management, 16(June 1991), 49-66. https://doi.org/10.1177/031289629101600103

Fikrian, H., Hasan, A., \& A, A. A. (2017). Pengaruh Kualitas. JOM Fekon, 4(1), 265-279. https://doi.org/10.1017/CBO9781107415324.004

Huque, A. S. (2011). Accountability and governance: Strengthening extra-bureaucratic mechanisms in Bangladesh. International Journal of Productivity and Performance Management, 60(1), 59-74. https://doi.org/10.1108/17410401111094312

Iskandar, D., \& Setiyawati, H. (2015). The Effect of Internal Accountants' Competence on the Quality of Financial Reporting and the Impact on the Financial Accountability. International Journal of Managerial Studies and Research, 3(5), 55-64.

Krismiaji, (2010). Sistem Informasi Akuntansi. Yogyakarta: UPP AMP YKPN

Lembaga Administrasi Negara. (2009). Standar Pelayanan Publik. Jakarta: Pusat Kajian Manajemen Pelayanan

Peraturan Menteri Dalam Negeri Nomor 20 Tahun 2018 tentang Asas Pengelolaan Keuangan Desa

Puspasari, O. R., \& Purnama, D. (2018). Implementasi Sistem Keuangan Desa dan Kualitas Laporan Keuangan Pemerintah Desa di Kabupaten Kuningan. Jurnal Kaj̈an Akuntansi, 2(2), 145. https://doi.org/10.33603/jka.v2i2.1719

Radarcirebon.com

Ramon, Dolly. (2014). Pengaruh Sistem Pengendalian Intern Terhadap Akuntabilitas Keuangan (Studi Empiris Pada Inspektorat Kota Se Provinsi Sumatera Barat. Jurnal Akuntansi Fakultas Ekonomi Universitas Bung Hatta.

Rosyidi, M., Azlina, N., \& Putra, A. A. (2018). Pengaruh Transparansi, Kompetensi dan Sistem Pengendalian Internal terhadap Akuntabiliats Pemerintah Desa Dalam Pengelolaan Alokasi Dana Desa. JOM FEB, 1(1), 1-14.

Setiawan, A., Haboddin, M., \& Wilujeng, N. F. (2017). Politik Indonesia. Politik Indonesia: Indonesian Political Science Review, 2(1), 1-16. Retrieved from http://repository.uinjkt.ac.id/dspace/bitstream/123456789/31700/3/Haniah Hanafie.pdf

Suprihastini, E., Akram, M. M., \& Santoso, B. (2017). Effect of Regional Financial Accounting System, Internal Control Systems and Regional Financial Audit on Financial Accountability of Local Government. International Conference and Call for Papers, Jember, 830-852.

Undang-Undang Nomor 6 Tahun 2014 tentang Desa

Widyatama, A., Novita, L., \& Diarespati. (2017). Pengaruh Transparansi, Kompetensi Dan Sistem Pengendalian Internal Terhadap Akuntabilitas Pemerintah Desa Dalam Pengelolaan Alokasi Dana Desa (ADD). Berkala Akuntansi Dan Keuangan Indonesia, 2(2), 1-20.

Yesinia, N. I., Yuliarti, N. C., \& Puspitasari, D. (2018). Analisis Faktor yang Mempengaruhi Akuntabilitas Pengelolaan Alokasi Dana Desa. Aset (Akuntasi Riset), 10(1), 105-112. 